University of Louisville

ThinkIR: The University of Louisville's Institutional Repository

Electronic Theses and Dissertations

$5-1912$

\title{
Analysis of water-insoluble proteins of flesh : an application of Van Slyke's method of analysis of pure proteins.
}

H. H. McGregor

University of Louisville

Follow this and additional works at: https://ir.library.louisville.edu/etd

\section{Recommended Citation}

McGregor, H. H., "Analysis of water-insoluble proteins of flesh : an application of Van Slyke's method of analysis of pure proteins." (1912). Electronic Theses and Dissertations. Paper 950.

https://doi.org/10.18297/etd/950

This Master's Thesis is brought to you for free and open access by ThinkIR: The University of Louisville's Institutional Repository. It has been accepted for inclusion in Electronic Theses and Dissertations by an authorized administrator of ThinkIR: The University of Louisville's Institutional Repository. This title appears here courtesy of the author, who has retained all other copyrights. For more information, please contact thinkir@louisville.edu. 
AIALYSIS OF WATER-INSOLUBLE PROTEINS OF FIESH.

An Application of Van Slyke's llethod of Analysis of Fure Proteins.

by

H. H. MCGREGOR

1912.

Submitted in partial fulfillment of the requirements for the degree of Waster of Saience in Chemistry, in the Arts Department of the University of Louisville. 


\section{ANALYSIS OF WATER-INSOLUBLE PROTEITS ON FLESH.}

\section{An Application of Van Slyke's liethod for Analysis of Pure Proteins.}

"The fundamental importance of a definite morledse of the quantity of each amino acid yielded by the several food proteins justifies the expenditure of much effort in studying the analytical mothods in order that these nay be improved or their limitations derinitely ascertained." I "Pron the standpoint of physiolocical chemistry it is highy desirable that the present very linited knovledge of the proteid substarces of flesh be increased i 2 The desirability of a mowledge of the amino acid content of food proteins hes led to much experimentation looking towards a nethod that will yield quantitative results without involving excessive time or manipulation in the analysis. An important method was olaborated by Van clyke "enabling one to attain an insight into the composition of protoins by methods wich require but small amounts of neterial and yield approximately quantitative results indicatine the nature of all the nitromonous products yielded by complete acid hydrolysis. The analysis is beced not on the isolation of the amino actas but on dotominations

Osbome and Guest: Journ. Biol. Chen, xi, 335, (1911).

₹Trombridge and Grindley: Joum. Aner. Chen. Soo. xxviif, $470,(1000)$.

3 Joum. Biol. Chen, ix, 185; $x, 15$, (19i1). 
of their characteristic chemical groups." : The present paper describes the results of an attempt to apply the method devised by Van slyke to the determination of the amino acid content of food proteins without a preliminary separation of the individual proteins of the naterial.

The later nethods of protein analysis have been built up theough the labors of meny investicators. This paper reviews briefly the various analytical methods that have been used. The method of van siyke is then described. Then follow some considerations arising from the attempt to analyze a complex mixture such as flesh in which. nitrogenous substances other than proteins are present. Initations of the application of this method are pointed out. InalIy, the experinental part of the present paper describes the nethod and the results obtained in the analyses of samples of (a) edestin, (b) dried beef and (c) dried pork.

PART I. ANALTTICAL UETHODS.

That the simple proteins yield on decomposition crystalline end products was know as long aro as 1818 when Proust discovered leucine in the decomposition products of cheese. In 1820 Braconnot ${ }^{2}$ obtained glycocoll from gelatine and meat by boiling with sulphuric acid. Thirty ycars later Itebig and linterberger found tyrosine among the end products of hair by treatment with boiling sulphuric acid. As better

\footnotetext{
Proust: Ann. de Chim. Phys., 10, 40, (1818).

ann. Chim. Phys., 13, 113, (1820).

3 Annalen, 71 , 70, (1849).
} 
methods were found for preparing and identifying the end products, other amino acids were slowly added to the list. Up to 1892, in addition to the substances mentioned above five other substances had been prepared, serine from silk glue, aspartic and glutamic acids from vegetable al bumins, alanine from the fibroin of silk, and amino isovalerianic acid or valine prepared by schulze' in 1892. In 1889 Drechsel ${ }^{2}$ showed that a considerable proportion of the products of protein hydrolysis were strongly basic substances belonging to the class of diamino acids. He mas the first to use phosphotungstic acid as a precipitant for protein cleavage products, and by its aid he found lysine, a diamino caproic acid in casein. Hedin ${ }^{3}$ prepared arginine and to these two basic compounds Kosse14 in 1896 added histidine discovered by him as a decomposition product of sturine, the protamine of the spernatic fluid of the sturgeon. Since then it has

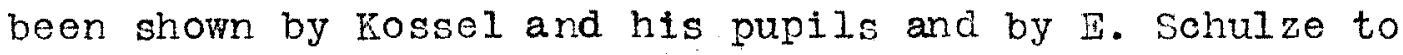
be a widely distributed end product. The three basic substances lysine, arginine and histidine were called by Kosse ${ }^{5}$ the hexone bases. He succeeded in working out methods for their quantitative estimation based on their precipitability with phosphotungstic acid. In 1901 Homer was able to demonstrate the vide distribution of the

\footnotetext{
'Zeitschr. f. physiol. Chem., 17, 193, (1892).

2Ber. der sachs. Ges. d. Wiss., 1889, 1890.

${ }^{3}$ Zeitschr. f. physiol. Chem., 21, 155 and 297, (1895).

${ }^{4}$ Ibid., 22, 176, (1896).

${ }^{5}$ Deutsche red. Wochenschr., 1898.

${ }^{3}$ Zeitschr. f. physiol. Chem., 34, 207, (1901).
} 
the sulphur-containing anino acid, cystine, while an acid of an entirely new type - tryptophane, a derivative of indole - was isolated by Hopkins and Cole!.

Recarding the development of analytical methods up to 1900, liann ${ }^{2}$ gives the following outline: The most important methods for determining quantitatively the decomposition products of proteins have been worked out by schulze, Hausmann and others. Hausnann's method for determining the distribution of nitrogen in the protein "molecule consists of the following operations:-

1) One gram of the substance under investigation is hydrolyzed with boiling hydrochloric acid.

2) The nitrogen which has been split off as $\mathrm{NH}_{3}$ and which is present as $\mathrm{NH}_{4} \mathrm{Cl}$ is distilled off with magnesia. This nitrogen is the so-called "amid-nitrogen", ammonia nitrogen, or readily displac eable nitrogen.

3) The fluid free from ammonia is precipitated with phosphotungstic acid and the nitrogen present in the precipitate is determined by Kjeldahl's method. This nitrogen is the diamino nitrogen or basic nitrogen of arginine, lysine, histidine.

4) The nitrogen which is not driven off by mannesia and is not precipitated by phosphotungstic acid is then determined by $\mathrm{Kjeldahl's} \mathrm{method} \mathrm{as} \mathrm{the}$ mon-amino nitrogen.

It is seen that this prodedure does not effect the complete separation of the end products, these substances being destroyed in the analysis. The first practical method for the isolation of amino acids was devised by Emil. Fischer, whose phenomenal researches on this subject began to be published in 1901. In the Fischer method the amino acids are converted into their volatile ethyl-esters, separated

IJourn. of Physiol., 27, 418, (1901).

${ }^{2}$ Chemistry of the Proteids, 1906, 75. 
-into fractions by distillation, the fractions reconverted into amino acids by boiling with water or barium hydroxide and then eparated by fractional crystallization. In practice the protein is hydrolyzed by boiling with hydrochloric acid for several hours at a temperature of $125^{\circ}-140^{\circ}$. The acid and water are evaporated off in vacuo, absolute alcohol added and the mixture saturated with $\mathrm{HCl}$ gas for esterification. To complete the esterification the alcohol and acid are evaporated in vacuo and a second or even a third treatment of alcohol-hydrogen-chloride given. The black pasty mass of esters is in the form of hydrochlorides. The esters are freed from hydrochlorides by barium hydroxide at low temperature and the mixture of esters extracted from the mass with ether. The esters are then fractionally distilled at less than one millimeter pressure. The distillate comes over from $80^{\circ}$ to $200^{\circ}$, generally received in four fractions. These four fractions are then saponified separately and the resulting ar:ino acids are isolated by crystallization. In a few cases other processes are used to.isolate individual amino acids. Glutanic hydrochloride is formed in and, after cooling, precipitates from the hydrolyzed mixture, being insoluble in concentrated hydrochloric acid. Glycine ester hydrochloride precipitates out almost wholly from the alcohol-hydrochloric acid mixture. A large portion of the original material remains behind after the ether extraction of the esters as a carbonaceous mass of unknow composition; in fact at every stage of the process some material is lost. 
The best results that have ever been obtained by this method are those of Obborne with vegetable proteins, where about 75 per cent of the products were recovered. jwost of the results account for only about 60 per cent of the end products. Another objection to the Fischer method is the large quantity of material required for esterification, at least 100 grams and preferably 300 or 400 grams being used.

PART II. THE ANAIYIICAL IETHOD OF VAN SIYKE. 1. ermination of Aliphatic Amino Groups.

In 1910 Van slyke published a prelininary report' of a method for the quantitative determination of aliphatic anino groups, showing applications to the study of proteolysis and proteolytic products. Later a complete method ${ }^{2}$ appeared. Feference is made to the reaction of aliphatic anino groups with nitrous acid:

$$
\text { R. } \mathrm{NH}_{2}+\mathrm{HNO}_{2}=\mathrm{F} . \mathrm{OH}+\mathrm{H}_{2} \mathrm{O}+\mathrm{N}_{2}
$$

"As early as 1875 sachs and Tormann made this reaction the basis of a method for quantitative determination of anino groups. Since then a number of methods based on this reaction have appeared, none of which have possessed such simplicity, rapidity and accuracy as would warrant their adoption for general use in chemical and biological problems." The mechanical basis of the new method is an apparatus consisting in the main of a small reaction vessel from which a narrow bore glass tube, equipped with a stop cock, leads

Ber., xliii, 3170, (1910).

Journ. Biol. Chem., ix, 185, (1911). 
to a gas burette or nitrometer, bearing a leveling bulb. The burette is in turn connected through a stopcock with a Hempel absorption pipette filled with alkaline permanganate solution for the absorption of nitric oxide. The apparatus forms a closed system. In operation, acetic acid and a strong solution of sodium nitrite are introduced into the reaction bottle. Advantage is taken of the spontaneous decomposition of nitrous acid with formation of nitric oxide:

$$
2 \mathrm{HNO}_{2}=\mathrm{HNO}_{3}+\mathrm{NO}
$$

to displace all the air in the apparatus with nitric oxide. A solution of the amino substance is then with suitable precautions run into the nitrous acid solution, evolution of nitrogen mixed with nitric oxide resulting. The oxide is absorbed by the alkaline permanganate solution and the pure nitrogen measured in the gas burette. Using this apparatus Van slyke made many determinations of separate solutions of the various amino acids and found that "every known amino acid obtained fron proteins by acid hydrolysis reacts quantitatively with one and only one nitrogen atom, except lysine, which reacts with two, and proline and oxyproline which do not react at all. Or, all the amino acids react with all their nitrogen, except tryptophane which reacts with one-half, histidine with one-third, arginine with one-fourth and proline and oxyproline with none." The complete determination of the amino acids can be fintshed in a few minutes and the error kept within $\pm 0.05 \mathrm{mg}$. of nitrogen, equaling the accuracy of the Kjeldahl and Dumas methods. 
2. The Analysis of Proteins.

lleusnann's method for determining the distribution of nitrogen. in the protein molecule has beon referred to. By a combination of this ceneral method, much modified and improved, with the above-described process for estimation of aliphatic amino groups, Tan slyke has elaborated a method which "vields approximately quantitative results with snall amounts of material and indicates the nature of all the nitrosenous products yielded by complete acid hydrolysis of proteins." The results show the distribution of nitrocen among the following substances or groups of substances: amonia, melanin, cystine, arginine, histidine, lysine, the anino-nitrogen and also the non-amino nitrogen of acids not precipitated by phosphotungstic acid. The foljowing is a sumary of the steps in the Van Slyke analysis:

a) Hydrolysis. The hydrolysis with 20 per cent hydrochloric acid is conducted in a tared flask. The progress of hydrolysis is followed by means of the method above described for determining aliphatic amino sroups.

b) Determination of $\mathrm{NH}_{3}$ (Amid Nitrogen). The hydrolyzed protein, freed as far as possible from acid, is mixed with a ten per cent sucpension of calcium hydroxide and the ammonia distilled off into decinornal acid under diminished pressure.

c) Nelanin itrogen. The melanin nitrogen is adsorbed by the undissolved lime during the amonia distillation. This residue is submitted to $\mathrm{Yjel}$ ahl determination.

d) Gystine, arginine, histidine and lysine are precipitated by phosphotungstic acid. These bases are redissolved - and determined by reactions based on tho pllowing marked chemical differences: 
LYSINE and CYSTINE contain only $\mathrm{NH}_{2}$ nitrogen, which is liberated with $\mathrm{HNO}_{2}$.

ARGININ contains one aliphatic amino group and three nitrogen atoms in the guanidine group. $\mathrm{HNO}_{2}$ therefore liberates one-fourth of its total nitrogen.

FISTIDIII contains one aliphatic anino roup and two nitrogen atoms in the inidazole roup. HNO liberates one-thind of its nitrogen.

ARGININE whon bolled with alkall evolves one-half of its nitrocen in the form of $\mathrm{MH}_{3}$, the initial decomposition being represented, accordine to experiments by Schulze and minterstein,

$$
\mathrm{O}_{3} \mathrm{H}_{1} \mathrm{~N}_{4} \mathrm{O}_{2}+\mathrm{H}_{2} \mathrm{O}=\mathrm{C}_{5} \mathrm{H}_{1} \mathrm{H}_{2} \mathrm{O}_{2}+\mathrm{CO}\left(\mathrm{NH}_{2}\right)_{2}
$$

The urea then yields $\mathrm{CO}_{2}$ and $\mathrm{NH}_{3}$, and the entire decomposition may be formulated,

$$
\mathrm{C}_{6} \mathrm{H}_{14} \mathrm{~N}_{4} \mathrm{O}_{2}+2 \mathrm{H}_{2} \mathrm{O}=\mathrm{C}_{5} \mathrm{H}_{12} \mathrm{~N}_{3} \mathrm{O}_{2}+2 \mathrm{NH}_{3}+\mathrm{CO}_{2}
$$

CYSTINE contains one aton of sulphur which may be oxidized by innition with $\mathrm{Cu}\left(\mathrm{NO}_{3}\right)_{2}$ and weighed as $\mathrm{BaSO}_{4}$.

Four determinations suffice to distribute the nitrogen of the bases among the four amino acids:

A. Distillation with alkali One-half arginine $N$.

B. Tjeldahl determination

$A+B=$ Total nitrogen

c. Determination of amino groups one-fourth arginine $\mathrm{H}$. one-thira histidine $i$. Total cystine $\pi$. Total lysine $\mathrm{N}$.

D. Oxidation of cystine sulphur Cystine $\mathrm{F}$. Therefore,

$$
\begin{aligned}
& \text { Arginine } N=A \times 2 \\
& \text { Histidine } N=3 / 2(A+B-C-3 / 2 A) \\
& \text { Cystine } N=D= \\
&\text { Lycine } N=\text { Total } N-\text { (arg. }+ \text { cyst. } N+\text { hist. } N)
\end{aligned}
$$

e) Amino acids not precipitated by phosphotungstic are determined in two croups:

1) Group reacting with ail nitrogen in anino fom,Glutanic acid, aspartic acid, tyrosine, phenylalanine, serine, leucine, isoleucine, valine, olanine, glvcine.

2) Veterocyclic amino acids, - proline, oxyproline and troptophane.

The principal uncertainty of the van slyke method as above outlined appears to be connected with the detemination of cystine and tryptophane. Tan slyke has show by control experiments' that about one-half of the cystine originally present is altered during the hydrolysis with acids further, 
an amount of cystine containing 0.5 per cent. of the total cystine nitrogen remains in solution when the bases are precipitated. In view of these facts it would appear that by the method used accurate estimation of cystine is impossible, although van slyke has obtained fairly satisfactory results by an empirical nethod of calculating a correction for the cystine figure, from experimental data showing the cystine decomposed by hydrolyses of varying durations. The nitrogen compounds resulting from the decomposition of the cystine will introduce errors into the other determinations. This liability to erroneous results recoives no emphasis in van Slyke's discussion. It may be surcested here that a determination of the cyctine sulphur. present immediately after hydrolysis would furnish data which could serve as a basis for the distribution of the nitrocen due to cystine at the various stages in the analysis. Tryptophene undoubtedly interferes with the accurate partition of nitrogen amone the amino acids. Van SIyke's experiments with pure tryptophane show the possibility of its partial precipitation with the "base" fraction. Of the two nitrogen atoms in tryptophane, one forms part of the indol ring and therefore does not react with ritrous acid: on the other hand, in the Van SIyke aralysis no ascinnment is made for the nitrogen resulting from the nitrous acid decomposition of the a-amino eroup of tryptophane. The fact is that tryptophane is largely altered during the acid hydrolysis! and consequenty only traces appear amone the

Irann: Chemistry of the Proteids, 1900, 54. 
end products. Osborne and Guest! conclude that "no method exicts whereby tryptophane can be estimated with any approach to accuracy. It may well be that tryptophane forms a not inconsiderable part of most of the proteins and that much of the part still unaccounted for may be made up of this amino acid.

\section{PART III. THE ANALYSIS OF FLESI.}

In attenpting to apply the above method of nitrogen distribution to the analysis of the cleavage products of flesh the problem of assigning the nitrogen to the compounds in which it originated becomes more complex. Two facts confront the investigator:

1. Approximately 12.5 per cent of the nitrogen content of dead muscle is in the form of non-protein substances. ${ }^{2}$

2. The cold water extract of raw beef contajns about 13.56 per cent of the total protein of the flesh. ${ }^{3}$

If water be used to remove the non-protein bodies the washings contain some of the protein. If the water extractives are not removed their presence vitiates any approach to accuracy in the analysis.

Nitrogenous Substances of Flesh.

The composition of muscles of different animals varies greatly, although it should be stated that the nitrogen percentage shows remarkable constancy. The average amount of nitrogen in fresh lean meat is 3.4 per cent. 4

1 Journ. Biol. Chem, ix, 350, 1911.

3 Hammarsten: Text Book of Physiol. Chern, 1911, 572.

${ }^{3}$ Trowbridge and Grindley: Journ. Amer. Chem. Soc., xxviii, 480, 1906.

4Iammarsten: Text Book of Physiol. Chem., 1911, 571. 
Elementary analyses of flesh made with great care by Argutinsky! show the average nitrogen in fat-free dry ox-flesh to be 15.3 per cent. Salkowski finds that 87.52 per cent of the nitrogen of beef-flesh is present in the form of protein, the balance as "other soluble bodies". The non-protein nitrogen exists partly as nitrogenous extractives, consisting chiefly of creatine, also the purine bases hypoxanthine and xanthine besides guanine and camine, but chiefly hypoxanthine. ${ }^{3}$ These nitrogenous but non-protein constituents may be separated from the main protein mass by suitable solvents but as above stated, soluble proteins are removed in the process.

Cold water Ertracts of Faw Flesh.

It has been shown by Trowbidre and Grindley ${ }^{4}$ that "the cold water extract of raw flesh contains a marked quantity of the total protein of the flesh, consisting chiefly oi proteins coagulable by heat together with some which do not coagulate by heat but are precipitated by saturating their solutions with zinc sulphate. These investigators found that the water extract of raw beef from which all visible fat and connective tissue were removed, has the composition, expressed in percentage of the fresh substanee, shown in the following table prepared from figures presented in their report:

I Hammarsten: Text Book of Physiol. Chem., 1911, 571. I Ibid., p. 572 .

3 Ibia., p. 545 .

4Journ. Arer. Cher. Soc., xxviii, 469, (1906). 
Water

Protein

Insoluble in cold water soluble in cold water Organic extractives I!itrogenous Ash
73.80

18.96$$
2.51
$$

1.83

1.80
3.04

.92

The method of analysis of flesh that this paper describes must be carried out after thorough extraction of the material to remove all non-protein nitrogen. The considerable anount of protein in the extract should be examined also, efter separation by coagulation, saturation or other suitable reans. In the following analyses the deteminations were made only upon flesh washed with cold water, the extract being discarded owing to insufficient time for its analysis.

$$
\text { PAIT IV: EXPERIHEITAL. }
$$

1. Apporatus .

a) Aminometer. An essential part of the van siyre method is the mechanical device for measuring the nitrogen evolved in the nitrous acid decomposition of aliphatic amino groups. This apparatus may be termed an "arninoneter". L brief description of it is given in part II of this paper. In the present analysis it was not, however, found expedient to purchase a duplicate of the original apparatus. Various articles of assorted glassware were therefore brought into requisition. Semi-disabled burettes, a short-stemed tap funnel, a graduated levelling bulb, with other appropriate vessels were assembled, connected as. in the Van Slyke dpparatus with snall bore tubing, and mounted with the aid of numerous 
clamps on an iron ring stand. The aninometer thus constructed is shown in the figure. The reaction bottle $D$ is of $40 \mathrm{cc}$ capacity. It is removable. A rubber stopper which fits securely into the neck of $D$ connects the bottle with burettes $A$ and $B$ and with tube $C$ from the gas burette. Burette $A$ is connected with $D$ by bent glass tubing of $6 . \mathrm{mm}$ bore, the tubing, passing to the bottom of $D$. A contains water and serves the double purpose of (a) displacing air or other gas from $D$ and forcing it into gas burette $F$, and (b) receiving solution forced back from $D$ by the nitric oxide generated in the reaction bottle. Burette $B$ has a capacity of $10 \mathrm{cc}$ and contains the arnino solution to be analyzed. Tube $C$ from $D$ leads through a paraffined rubber tube equipped with a pinch cock, to the ge.s burette. Gas burette $\mathrm{F}$ consists of a graduated leveling tube, to the base of which levelline bulb $I$ is connected by flexible rubber tubing. Into the top of. $F$ is fitted a threo-holed rubber stopper, admitting (a) gas fron D, (b) gas from absorption bulb $\mathrm{H}$, and (c) a ben tube 15 of $1 \mathrm{~mm}$ bore, tightly fitted outside with a removable rubber plug. $\mathbb{N}$ serves as an outlet for air expelled from $D$ in the flushing of the apparatus preparatory to the collection of the nitrogen. Tube $G$ conrects F directly with absorption bulb H, which consists of a aropping funnel used in liev of a Hempel pipette. K is a heavy side-necked flask connected with the leg of $\mathrm{H}$, and contains permanganate solution. All the rubber connections are veli, parafined. The gas burette was recalibrated by the aid of a corrected burette: a table of corrections for the gas burette is appended to this paper.

In operation, tube $G$ is filled witin permanganate 


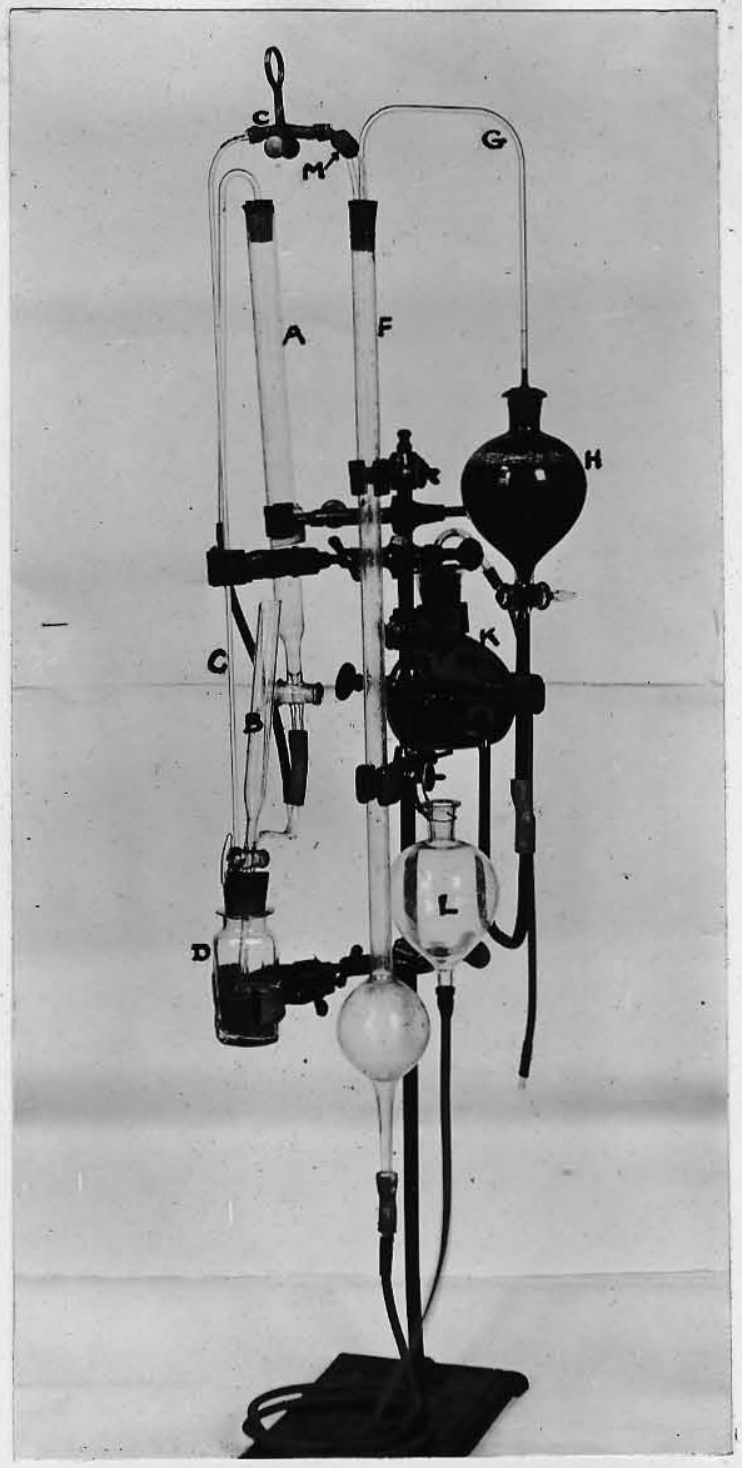


forced through $\mathrm{H}$ by lung pressure on the tube leading from K. The water in the gas burette is raised by the levelling bulb unti] it is within one centimeter of the top and is held in this position by pinching the rubber tube attached to the levelling bulb. A is half filled with nitrogen froe water, the outlet tubes from $A$ and $B$ being filled with water below the stop cocks. The amino solution diluted to $10 \mathrm{cc}$ is placed in $B$. All the cocks are closed except $c$ and 0 . 25 cc of a 30 per cent solution of sodium nitrite are placed in the reaction bottle $D$ with 7 cc clacial acetic acid, and D.is fittod securely into the eubber stopper. (It was found unnecessary to wire it in.) Mild evolution of nitric oxide ensues. This is allowed to escape through $C$ and $\mathrm{H}$ for five minutes. It is found that by this time all the air has boen displaced from the nitrite solution. Cock A is now opened and by pressure on the water in $A$ it is forced into $D$ where the liquid is allowed to rise through tube $c$ until a few drops hove passed into F. Cock $c$ is promptly closed, cock A being left open to receive solution fron $D$. By raising the levelling bulb the gas burette is freed from all gas through If, this tube being allowed to fill with water from $F$. If is then closed securely with the rubber plug. Luring the expulsion of air from the burette the nitric oxide has conerated in sufficient amount to provide space in $D$ for the reception of the amino solution. Cock $A$ is now closed, c opened, the levelling bulb lowered to lessen the pressure, and the amino solution slowly run into $D$ as far as the lumen 
of the cock. A is rinsed trice with small amounts of water and these are mu into D. Cocl II may now be opened so that the nitric oxide may be absorbed continuously. After the reaction has continued twenty-five minutes $D$ is shaven cently for one minute. The gas is then ariven fron $D$ and $C$ into $F$ as in the initial flushine of the epparatus, $c$ is closed and A reopened. Complete absorption is accompliched by forcing the gas from $F$ into It and ently shakine $\mathrm{H}$. by sweying the whole apparatus. The ger may bo tested for complete absorption by ropeated measurement.

To test tho efficiency and accurac of the apparatus a detemination of urea was made. Van slylo's statemont that $u$ urea roacts in sicht hours with all of its nitrogen vas confirmed. .2084 grans of Jercle's urea were dissolved in mater and made up to $100 \mathrm{cc}$. $10 \mathrm{cc}$ of this colution were used for determination in the aminometer, the notiod above outlined boing followed with the excention of the timo of reastion, which was extended to exactly ten hours. A blank experiment nas performed under identical conditions, substituting 10 co nitrogen-free water for tho uroa solution. The results rore calculated, as wore tho rosults of all subsoquent ceteminations witl the aminometer, fror tho ceneral equation:

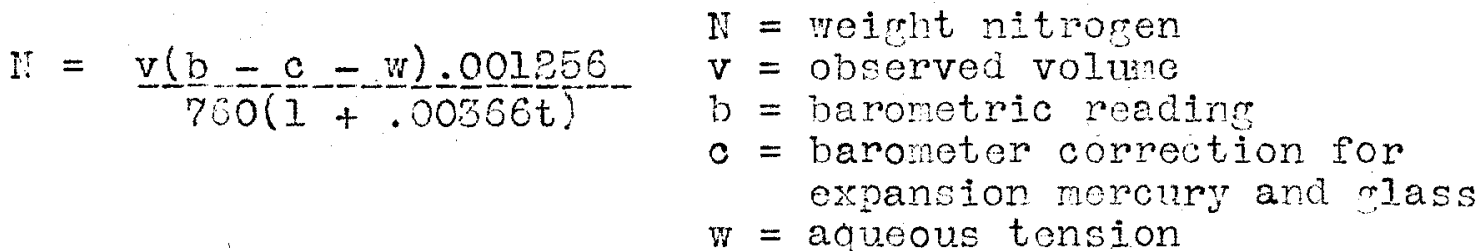

$$
\begin{aligned}
& t=\text { observod temperature }
\end{aligned}
$$


UNEA - 19.5 c gas - temp. 24. - barometer $755 \mathrm{~mm}$.

$$
\mathrm{H}=\frac{19.5(755-2 .=22) \cdot .001256}{760(1+.00366 \times 21)}=0.02178 \mathrm{E}
$$

BLAIK - 2.z cc gas - temp. $24^{\circ}$ - baromoter $758 \mathrm{~mm}$.

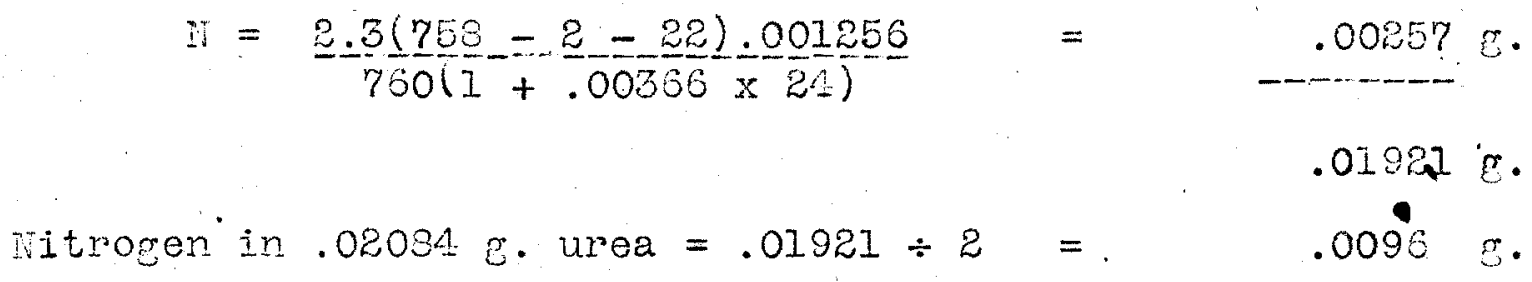
calculated for $\mathrm{CO}\left(\mathrm{NH}_{3}\right)_{2}: \mathrm{N}, 46.67$ per cent. Fround $\mathrm{N}, 46.11$ per cent.

The error here is approximately 0.6 per cent for urea. The time for reaction, ten hours, increases tho amount of foreicn nitrocon evolved. The error is therefdre likely to be very much less when the aninometer runs for the remular pertod of ono-half hour.

b) Barometer. Whe barometer used was the ordinary sinhon form nade by boiling mercury which had been introduced into a $7 \mathrm{~mm}$ bore U-tube sealed at one end. The constant correction made use of in the above equation for calculating nitrogen is not exact. Wheoretically the reading corrected for cubical expension of mercury and linear axpansion of glass would be represented

corrected height $=$ observed height $\frac{1}{1}+ \pm .0000085 t$ For readings between $20^{\circ}$ and $25^{\circ}$, and with barometer height between $755 \mathrm{~mm}$ and $760 \mathrm{~mm}$, the reduction $1 \mathrm{~s}$ approximately 1.5 nm. For the present analysis a reduction of $2 \mathrm{~mm}$ is sufficiently accurate.

c) Diminished Pressure Distillation Apparatus. This apparatus is similar to that used in the original van slyke 
method, with the exception that the double-necked distilling flask was replaced by a one liter ordinary balloon flask, with a three holed rubber stopper. Through one hole, 1 mm glass tubing passes to the botton of the flask through which air bubbles into the solution when the flask is evacuated. The air facilitates the distillation and effectually prevents bumping. The tube from a glass stop cock ente through another hole to allow the free ingress of air arter the reaction is complete and before the suction is renoved. A bent glass tube of $1 \mathrm{~cm}$. bore connects the dstillation flask with the receiver, the tube terminating in the body of the latter.

2. Analysis of Edestin.

a) Preparation. About 300 grams of crushed hemp seed were extracted with five per cent salt solution for three hours at $50^{\circ}$. The hot extract was filtered through cloth and again heated up to $60^{\circ}$. A large Buchner funnel was prepared using as filtering material filter paper pulp saturated with the saline solution. The extract was piltered through this by suction trree or four times, being heated up to $60^{\circ}$ before each filtration. The final iltrate was clear and colorless. The vessel containing the liquid was placed in a large basin containing hot water and was allowed to stend over night, thus insurine slow crystallization. The supernatant liquid was poured of as completely as possible and the white suspension taken arein into solution with hot salt solution, the "volume at this time being dout one liter. wing was diluted with two volumes of distilled water and in about two hours a 
perfectly white precinitate had settled. This was filtered through a suchner funnel and washed ith water until frec from chlorides. Before the powder becene ary it was renoved Prom the funnel and shalen with alcohol, again filtered ard sucked nearly ary. At this stare the mass was snow white. The raterial was placed on a match elass in a vacuun desiccator over sulphric acia. After standing for twelve hours e slightly yellow larem had formed on the surface. Wien cround the vaterial furnished a nearly white, fine, dusty pomder.
b) Hydrolysis.
3.0208 spans of the edostin as above propared were placeci in a small tared flast with $15 \mathrm{cc}$ 20 per cont iyarochloric soid. Whis was comected with a Noplins reflux condenser and placed in a boiling wator bath. The boiling was continued for two periods of seven hours cach. Ey this time the mass had become black. Whe flasi and contents weiched 52.79 grams. One cubic centineter was robod and the flask reweiched, chowing I.I grans of the material Withdrawn. Wis was detemined in the arinoneter. $39.33 \mathrm{cc}$ gas were evolved at $24^{\circ}$ and $758 \times \mathrm{mm}$. Iydrolysis vas continued for sevon hours nore, the solution cooled ad the flask weiched, showing, with the constant tare of the flask declucted $(34.35$ e), 17.21 srams. 1.1 crams were vithdramn, which yielded 39.13 cc gas at $22^{0} 758 \mathrm{~mm}$. It was therofore concluded that the edestin was completely hydrolyzed.

c) Total Nitrogen. The hydrolyzed material was tronsferred to a distilline flask and as ruch as possible of the FCl distilled off at $30 \mathrm{~mm}$ prossuro. The residue, a dart colored liquid containing some black spongy flocks, was 
taken up with mam water and diluted to 200 co in a neasuring flask. Two 10 co portions were removed for Kjeldahl

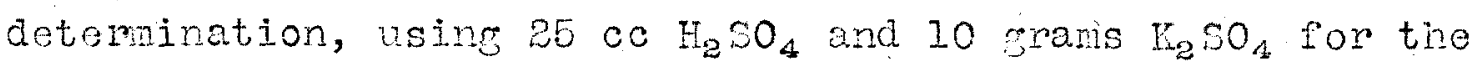
digestion. A blank experinent was also rub. No. $\frac{1}{2}$ neutralized 18.32 ce $\mathrm{N} / 10$ acid

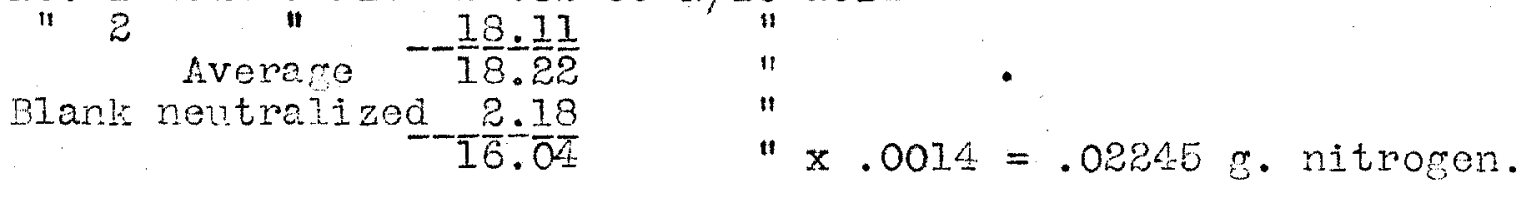
The remainder of the solution, $180 \mathrm{cc}$, therefore contained .4041 grons nitrogex which must be accounted for in the analysis.

d) Anid nitrogen. The $180 \mathrm{co}$ of hydrolyzed protein solution was transferred to the one liter flask of the distillation apparatus al ready described. 25 co of $\mathrm{J} / 10$ acid vere placed in each of the receiving flasks, with alizarin as indicator. To the protein solution were added 100 co alcohol and a ten per cent suspension of calcium Mydroxide to alkaline roaction. The distijlation was continued thirty minutes from a water bath, at $40^{\circ}$ and $30 \mathrm{~mm}$. $25.9 \mathrm{cc} \mathrm{N} / 10$ acid neutralized indicated .0362_Erams AIID N. A blanl dotermination showed no correction necescary for this figure.

e) Melanin vitrogen. The lime residue in the reaction flask became dark from adsorption of melanin. It was filtered off, washed iree from chlorides, and the filter paper with the lime and melanin digerted in a Kjeldahl flask for nitrogen estimation. A blank test was also conducted.

$$
\begin{aligned}
& 1: / 10 \text { acid neutralized }=7.89 \mathrm{cc}
\end{aligned}
$$

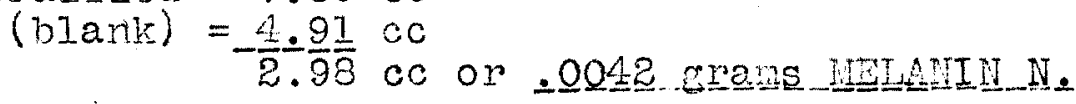


The high nitrogen content of the blank in this determination was probably due in part to the filter paper used which was of poor grade. It nay be noted that the blanks on each of' the three melanin determinations reported in this paper show hich nitrogen, pointing to impuritios in tie reagents.

f) Filtrate from lolanin. The filtrate was neutrolized with hydrochloric acid, concentrated to $100 \mathrm{cc}$ in vacuo and washed into a $200 \mathrm{cc}$ Brlenmeyer flask. $18 \mathrm{cc}$ concentrated hydrochloric acid were added, then an aqueous solution containing 15 grams phosphotungstic acid. A hoovy grayish precipitate of the basos was immediately throm dom. The flasir was placed in a boiling water bath until nearly all of the precipitate had dissolved, firteen minutes heatine beine recuirod before solution occurred. The flast was then alloved to stand for upwards of 100 hours. Tho precipitate mas washed and iltered, Van slyke's procedure being followed exeetly, a three inch Buchner funnel being fitted with a hardened rilter paper lining the botton and sides, and the precipitated basos washod repeatedly with a solution. of 3.5 por cent, hydrochloric coid and 2.5 per cent phosphotungstic acid until the calcium test becane negative.

g) Treatment of Precipitate of Bases. The procipitate nas carefully transferred to a liter bealser, the last traces of precipitate being ronoved from the hardened filter paper by discolving in 20 per cent sodium hydroxide. The beses. vere then brought into solution by cautiously adding 50 per cent sodium nyoroxide, phonolphthalein beine used in the beaker to prevent any rreat excess of alkali beine added. A 20 per 
cent solution of barium chloride was used to procipitate the phosphotungstate. It is important at this step that the bariun chloride adced be not excessive: its presonce causes a most undesirable bumping in the arginine detemination. The precinitated bariun phosphotungstate is filtered off on the " same hardened ilter paper used for the bases, washing being continued until chlorides are absont. The filtrate is concentrated in vacuo and some precipitated barium phospiotunstete filtored off; The filtrate was made up to $100 \mathrm{cc}$.

h) Gystine Witrogen. Fenedict's solution was used to detemine the sulphur content of the bascs, which ropresents the cystine present. Wis solution contains 200 grams crystallized copper nitrate and 50 crans potassium chlorate mede up to one Iiter: $10 \mathrm{cc}$ of the solution of the bases and 5 cc or Bonedict's solution were placod in a quartz evaporating disin, ovaporated to dryness on a vater bath and finally heated to redness four or itve minutes with the blast. The rosidue was ertiactod with 10 co of 10 per cent hydrochloric acid. A residue (of silica, probably) renained undiscolved. This we filtered off and washed to remove all traces of soluble material. The oxidized sulphur is nor present as sulphate and was determined in the usual maner by precipitation as bariun sulphate. ach millisrar of bariun sulphate represents $.06 \mathrm{mg}$. of cirtine nitroren, or, as one-tentl of the solution of tho bases was used, $.6 \mathrm{mg}$. in the total solution.

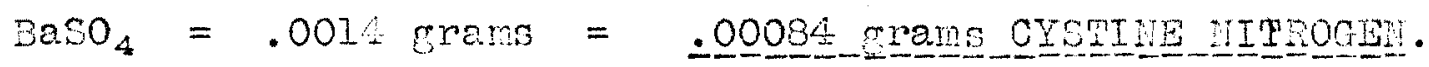

i) Arcinine vitroren. The van slyke aporatus for arrinine 
nitrogen consists of a joldahl flask in which are placed 25 cc of the solution of the basos and 12.5 prams potossiun hydroxide. This is comected with an upright condencer, in the top of mich a Folin absorption tube containine $16 \mathrm{cc} N / 10$ acid is inserted. Ton SIyte had round that under these conditions one-half of the arcinine nitrocen is evolved as $M_{3}$ aftei six hours centle boiline. At the end of six hours $100 \mathrm{cc}$ of water is added and the remoining amonia boiled off through the remular rjoldahl condenser and received in a flast which contains the acid from the Folin oulbs. In the edectin determination this apparatus was prepared and the nixture of bases and allali wero bolled in an oil bath at, $125^{\circ}$. During the reaction the bumping became so severe as to cause some of the acid from the rolin apparatus to back-flow into the rjoldahl flask, npoiline the detemination. A modification of the method was attenpted: for the polin bulbe vore substituted $7 \mathrm{~mm}$ bore glass tubine, leadins through the rjeldanl condenser to the standard acid. The alxali solution was boiled exactly six hours from an oil bati, when the roflux was revoved and the kjeldahl flask, after addition of 100 cc water, connected directy with the condenser. Ihot more than 50 ce of water were distilled over. $2.33 \mathrm{cc}$ of the $N / 10$ acid were found to have been neutralized; that is, one-fourtl of the total solution of tho bases had yielded one-half of its arsinine nitrogen, noytralizine $2.33 \mathrm{cc}$ acid. If all the arginine had reacted, the solution therefore contained nitrogen equivalent to $18.64 \mathrm{cc}$ decinomal acid, or

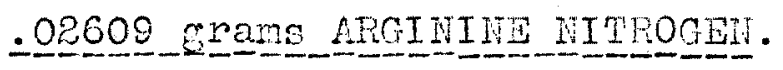

It is obvious that this figure for arginine nitrogen, which 
represents 6.5 per cent of the total nitrogen, is very much in error in viow of other careful analyses of edestin, which show arginine nitrogen to constitute about 26 per cent of the total. The failure of the material to react in accordance with the experiments performed by van slyke is not now understood.

k) Total Iitrogen of the Bases. To the residue from the arginine were added $35 \mathrm{cc}$ sulphuric acid and 25 grams copper sulphate. This mas digested and distilled, $19.84 \mathrm{cc}$ N/10 acid being neutralized. This, added to $2.33 \mathrm{cc}$ acid neutralized by part of the arginine, nitrogen, shows $22.17 \mathrm{cc}$ acld neutralized by one-fourth of the solution of the bases. $22.17 \times 4 \times .0014=.1241$ grams NITROG

1) Amino Nitrogen of the Bases. $10 \mathrm{cc}$ of the solution of the bases were determined in the usual way, yielding 8.45 cc of nitrogen at $23.5^{\circ}$ and $760 \mathrm{~mm}$.

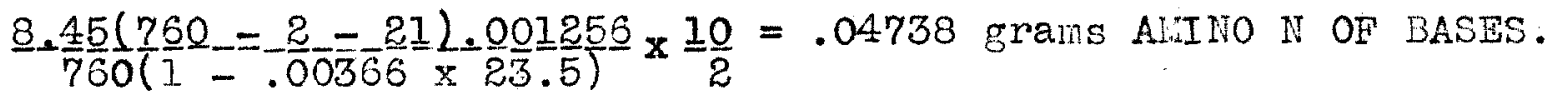

m) Filtrate from the Bases. This filtrate is strongly acid and is therefore neutralized with 50 per cent sodium hydroxide, then slightly acidified with acetic acid. The solution was concentrated under diminished prossure until salt began to crystallize in the flask. It was then made up to $200 \mathrm{cc}$ in a measuring flask.

n) Amino Nitrogen of the Filtrate. Two $10 \mathrm{cc}$ portions were taken and detemined separately in the aninoneter. No. I yielded 17.29 cc gas $-26^{\circ}-755 \mathrm{~mm}=.1898 \mathrm{~g} \cdot \mathrm{nitrogen}$.
No. 2 " 16.89 " .1898_grams AIINO N IN THE FILTRATE. 
o) Total Nitrogen of the Filtrate. Kjeldahl determinations were made on two $25 \mathrm{cc}$ portions.

$$
\begin{aligned}
& \text { Io. } 1=21.34 \mathrm{cc} \mathrm{N} / 10 \text { acid } \\
& \text { No. } 2=-\frac{21}{21} \cdot \frac{96}{90} \\
& \text { Average }=-\overline{2} \overline{1} . \overline{9} \overline{0}
\end{aligned}
$$

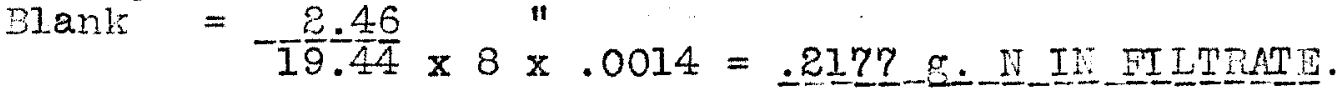

p) Histidine Mitrogen. Calculated by difference, equation given in Fart II, $2, d)=$.0856_E. IIIIIDINE III TROGEI.

q) Lysine vitrogen.

$$
\text { By difference, } \begin{aligned}
.1241- & (.0261+.0856+.0008)= \\
& .0116 \text { grans_LYSIME_IIIPOGII. }
\end{aligned}
$$

Reference was mace in connection with the arrinine results to the large error apperent. As the arginine figure is used as a basis for the calculation of histidine and lysine, it is evident that the above deteminations of theso two bases are not correct.

The following sumrary compares the results of the edestin analysis with the figures obtained by Van Slyke. Comparison is made with van slyke's "uncorrected" data inasmuch as the above determinations are not corrected for the solubility of the bases.

Results of Edestin Analyses in Percentages of Total Hitrocen. THIS PAPER

VAN SLYKI No. 1
VAN SLYKE No. 2
Grams

Ii found

\begin{abstract}
Ammonia it
Melan in $\mathrm{N}$

Cystine in

Arginine it

Mistidine $\mathrm{I}$

Lysine $\mathrm{F}$

Amino $I$
\end{abstract}

Filtrate

Mon-Anino $\mathrm{N}$ Filtrate
.0362

.0042

.0008 )

$.0261)$

$.0858) .1241$

$.0116)$

$.1898)$

$.0279\} .2177$

Percentage_l Percentace_I

Percentage II

3.96

1.05

$.20)$

$6.46)$

$21.18) 30.71$

2.87)

45.97)

$(5.97)$
$6.90)$
63.87
9.80

1.83

$.71)$

26.85)

3.63) 34.8

3.58)

$\left.\begin{array}{c}49.4 \\ 3.5\end{array}\right\} 52.9$
10.17

2.12 .82)

$25.45)$

$5 . 6 3 \longdiv { 3 5 . 8 }$

3.93 )

$48.6 ?$

$2.8\{51.4$ 
Fivon if the wide divergence of the figures for the individual bases is left out of consideration, it is evident that other discrepancies are altogether beyond the linits of exporimental error. Lacl of familiarity with the method is responsible for juch of the divergence. Also, the relatively enormous corrections sonetimes found necessary for impurities in the reagents hav to a large extent affected the accuracy of the results. 3. Analysis of Beef_⿲丶丶㇒一ㅗㄴ.

a) Preparation of the Haterial. The beef used was from the rump of a steer estimated to weich 1200 pounds and to be five years old. The neat was freed from all visible fat and connective tissue, then weighed and ground in a meat grinder. The finely macerated material was mixed with about two liters of cold water. This was thoroughly stirred and then filtered through cloth, most of the water being squeezed out by the hand. A second similar treatment was given the mass, as much water as possible beine expressed. The residue was free from blood and possessed a grayish white color. It was dried at $60^{\circ}$ for ten hours in an air bath, then eround, desiccated over sulphuric acid and weighed. The cround material lacked the true powdery quality of the edestin, and the mass possessed sone slight resiliency. It was gray in color. While weighing a sample of the dried meat, it was found to be extremely hygroscopic. Weight lean meat before washing $=251.5$ grams Weicht arter washing and drying $=45.2$ grans Water and extracts 82 . per cent.

b) Ash. 2.2946 grams of the beef powder were incinerated slowly in a porcelain crucible. A few crystals of amoniun nitrate were added during the heating. The pure wite 


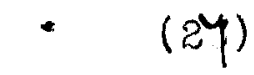

residue weighed .1036 gram, or 4.51 per cent of the dry substance.

c) Fat, or Total Pther ixtract. luch of the fat separated out in the washing. 13.3088 grams of the dried powder were extrected for four hours with ether in a soxnlet apparatus. The residue after distilling off the ether weighed 2.0331 grans, or $15.2 \dot{6}$ per cent of the aried material.

d) Hydrolysis. 4.7078 grams of dried beef (containing fat and ash) with $40 \mathrm{cc}$ of 20 per cent hydrochloric acid were heated in a tared flask to $120^{\circ}$ on an oll bath for twelve hour and eight hour periods with the following results:

Twelve hours hydrolysis: weight of solution, 49.03 grams.

2.29 grans in aminometer yielced $42.63 \mathrm{cc} \mathrm{N}, 23^{\circ}, 760 \mathrm{~mm}$.

Twenty hours hydrolysis: Heicht oi solution, 46.49 grams. 1.08 srams in aminometer yielded $21.0 \mathrm{cc} \Pi, 23^{\circ}, 760 \mathrm{~mm}$. The hydrolysis was therefore complete.

e) Total Nitrogen. After distilling off the hydrochloric acid the solution was diluted to $250 \mathrm{cc}$ and two $10 \mathrm{cc}$ portione withdram for rjelahl determination.

$$
\begin{aligned}
& \text { No. } 1=17.66 \mathrm{cc} \mathrm{N} / 10 \text { ac id } \\
& \text { NO. } 2=16 \cdot 25 \text { " } \\
& \text { Average } 17.3 \text { " } \\
& \text { Blank } \\
& -\frac{2}{5} \cdot \frac{0}{3} \\
& =.02142 \mathrm{~g} \cdot \mathrm{N} \text { in } 10 \mathrm{cc} \text {. } \\
& =.49266 \text {. } . N \text { in_230_cC USED FOR ANALISIS. }
\end{aligned}
$$

At this point the percentage nitrogen in the dried material can be shown. Deducting the figures for ash, 4.51 per cent, 15.26 per cent fat, together with the amounts of sdution removed during the nydrolysis and in the total nitrogen estimation, from the weight of the sample taken for analysis:

$$
\begin{aligned}
& \text { 4. } 1018 \times .9549 \times .8474 \times \frac{467}{49} \frac{9}{03} \times \frac{4541}{4649} \times \frac{230}{250} \\
& =3.2355 \text { grams dry protein substance. }
\end{aligned}
$$

This 3.2355 grams dry protein substance contained .49266 grams 


\section{(28)}

nitrogen, or 15.23 per cent. Mhis is in exaot aereoment with the percentage as found by Argutinsky roferred to earlier in this paper.

f) Amid Witrogen. This determination was conducted in the same manner as the edestin, with the exception that bariun hydroxide was substituted for calciun hydroxide. It was thought that the calciun hydroxide might be responsible for the high nitrogen figure in the blank experiment controlling the melanin detemiration. Later experiments, however, showed that this was not the case. $50 \mathrm{cc} \mathrm{N} / 10$ ac $1 a^{\circ}$ were used. 12.64 cc acid were neutralized, indicating ol?? rrams_AITD NIIIOGEN.

g) Melanin litrogen. The baryta residue was filtered off through filter paper of rood quality and digested ir a Kjeldahl flask, a blank being run at the sane time.

$$
\begin{aligned}
& \mathrm{N} / 10 \text { acid neutralized }=12.17 \mathrm{cc}
\end{aligned}
$$

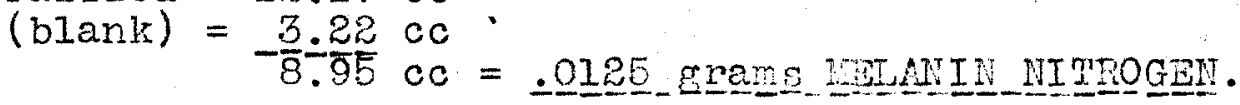

h) Cystine Nitrogen. $10 \mathrm{cc}$ of tho solution of the bases were treated with Benedict's solution. A trace of barium sulphate was obtained which was not appreciable.

j) Arginine litroten. 25 co of the solution of the bases were used, the deternination being carried out in the same way and at the sane time as for the edestin arginine, and a similor error appeared in the results. 3.59 co decinormal acid were neutralized. Therefore, $100 \mathrm{cc}=4 \times 3.59 \times .0014 \times 2=$

\section{.0402 grams ARGIIIIIE NITROGEII.}

k) Total Nitrocen of the Bases. The residue from arginine Yielded nitrogen $=23.46 \mathrm{cc} \mathrm{m} / \mathrm{I} 0 \mathrm{acid}$ arginine $=-\frac{3.59}{27.05} \times .0014 \times 4=.1515$ grans N_IN_BASES. 
by three treatments with dola water, one liter of water betng used each time and the meat thoroughly mixed to a suspension, then filtered throuri cloth. Sost of the water was pressed out - and the material aried for fifteon hours in en air bath at $35^{\circ}$. The dried meat weighed 51 grams, or 20.52 per cent of the ra: flesh. The dry material was slightly yellow in color, very hroroscopic, and possessed a faint meaty odor.

b) Ash. 1.8193 crams were determined for ash, the latter weiching . O71.0 mrems, equal to 3.9 per cent of the dry substance.

c) Pat, or lotal Ether Extract.. 15.3488 grans of the dried meat were extracted for four hours with ethor ir a soxhlet. The fatty rosidue weighed 8.0724 Erans, or 18.71 per cent.

d) Hydrolysis: 4.8769 grami of urextracted dried noat were hydrolyzed with hydrochloric acid by heatine to $130^{\circ}$ on an $0 \pm 1$ bath.

Poriod of Voight Crams co hydrolysis solution withdram nitrogen

$\begin{array}{ccccc}\text { I } 9 \text { hours } & 36.14 \mathrm{~g} \cdot & 1.15 & 27.85 & 760 \mathrm{~mm}, 25.5^{\circ} \\ \text { II } 18 \text { hours } & 34.84 \mathrm{~g} . & 1.13 & 29.25 & 755 \mathrm{~mm}, 26.5^{\circ} .\end{array}$

The nydrolysis is shom, to be complote.

c) Total itiogen. The solution was diluted to 200 co and tro 10 co portions determined.

No. 1 21.19 cc $1 / 10$ acid Blank $\underline{21} \div 2$ I⿳亠口冋. $"=.0269$ grams $I:$ in $10 \mathrm{cc}$. $=.4838$ grams IN in 180_cC USED FOR ANALYSIS.

Whe weight of dry protein substance used for analysis is therefore, $4.877 \times .7739 \times \frac{34}{3614} \times \frac{33}{3184} \times \frac{1}{20}=3.1815$ grams

The percentare nitrogen in the dry extracted material is 15.27. 
f) Amid itrogen. Calcium hydroxide was used to alstil over the ammonia. 22.79 cc $1 / 10$ acid were neutralized, indicating, -0319_Erams AIID IIIT ROGEI.

g) Nelanin Nitrogen.

$N / 10$ ac $1 \mathrm{~d}=10.76 \mathrm{cc}$

Blank $=-\frac{3}{2}-1 \frac{18}{5} \mathrm{cc}$

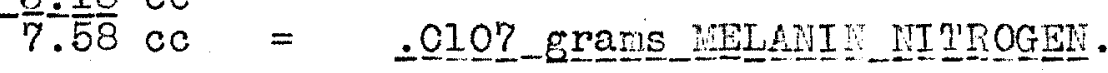

h) Cystine ititrogen. No sulphur was found.

j) Arginine Nitrogen. Mhis detemination was carried out at the same time and under the same conditions as the other arsinine experiments and is therefore subject to the same error. $4.39 \mathrm{cc} \pi / 10$ ac id were neutralized. Therefore,

$100 \mathrm{cc}=4 \times 4.38 \times .0014 \times 2=.0491$ Erams_ARGINIIE_NITROGEN.

k) Total nitrogen of the Bases.

25.55 cc $N / 10$ acid

$4.38 \mathrm{cc} "$. from arginine

$29.93 \quad x .0014 \times 4=.1676$ _grams IIITYOGEII IN_BASES.

1) Amino Nitrogen of Bases.

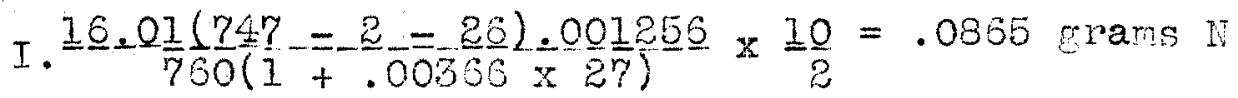

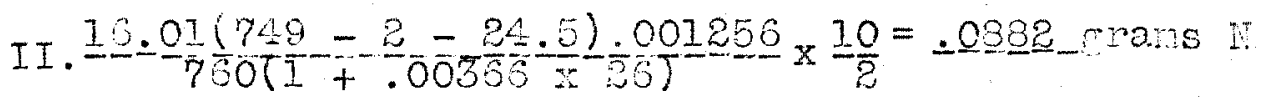
-O873-grams O OF BASES IN

m) Amino Vitrocen of the Niltrote. The solution was nade up to $200 \mathrm{cc}$.

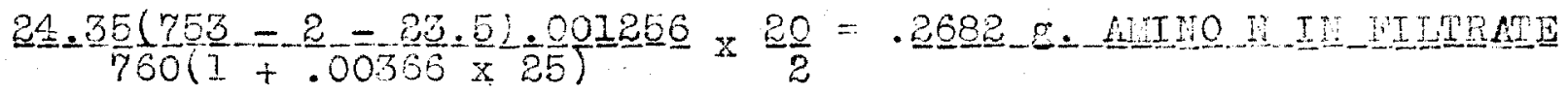

n) Total iitrogen of the Filtrate. $25 \mathrm{cc}$ portions used.

No. $1=31.08$ co $1 / 10$ ac id
No. $2=30.09$ "

Biank $\frac{4.5}{23} \cdot \frac{1}{5}-0014 \times 8=$

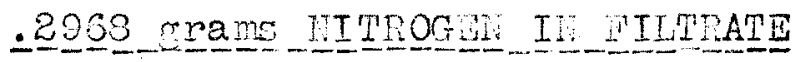


o) Migtidine Nitrogen. By calculation, .065e GLLE.

p) Lysine Nitrogen. By calculation, Sumary of Regults._Analysis of Loiod Porl Mesh.

ilitrocen in sample taken, .4838 mrams.

Mid if

Velanin

Cystine $n$

Arrinine

iistidine $\mathrm{T}$

Lysine $\mathrm{H}$

Amino

iiltrate

Non-Anino is

Filtrate
Pereentare of -1030 .

2.21

.0107

$.0 \overline{01})$

$.0652) .1676$

.0533 )

$10 . \overline{15})$

$13.47) 34.64$

$11.02)$

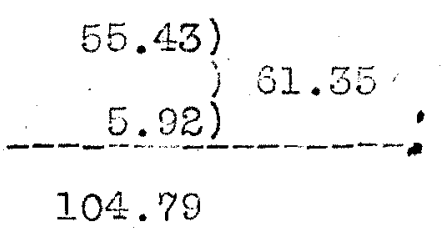

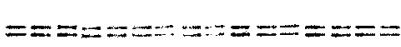

A comparison of the tables sumarizing the results of the beef. and pork analyses shows close similarity of composition with respect to the groups of nitrogenous constituents.

It is reaconable to expect, in view of the above analyses, that this nethod is capable of general application to the estination of the amino acias of pood proteins. 
Table of corrections for cas burette of Aninoneter.

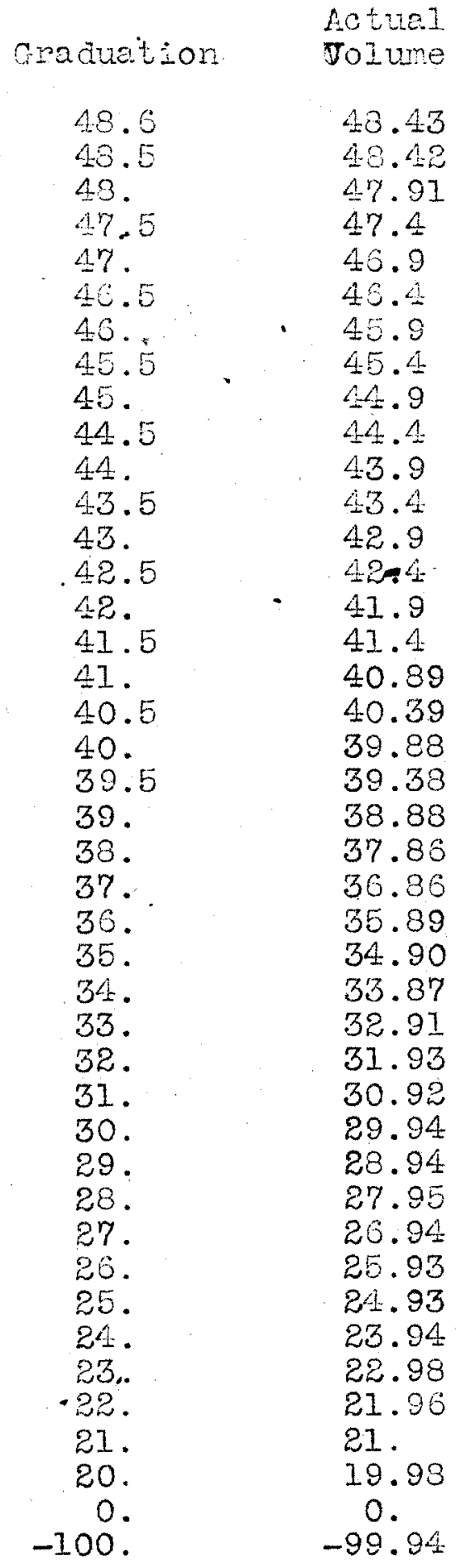

